Counsellia: Jurnal Bimbingan dan Konseling, 10 (2), $2020 \mid 190-203$

Copyright $@ 2020$ Universitas PGRI Madiun

ISSN: 2088-3072 (Print) / 2477-5886 (Online)

Available online at: http://e-journal.unipma.ac.id/index.php/JBK

DOI: 10.25273/counsellia.v10i2.7789.

\title{
Pemberdayaan Remaja Masjid di masa pandemi Covid-19 melalui workshop dan simulasi Konseling Sebaya
}

\author{
Ratna Sari $^{1}$, M Nurul Ikhsan Saleh ${ }^{2}$, Diana Nur Rahman ${ }^{3}$, Anita Aisah ${ }^{4}$ \\ ${ }^{1}$ Fakultas Agama Islam, Universitas Muhammadiyah Yogyakarta, Yogyakarta \\ ratna.sari@umy.ac.id \\ ${ }^{2}$ Fakultas Ilmu Agama Islam, Universitas Islam Indonesia, Yogyakarta \\ mnurul.ikhsan.saleh@uii.ac.id \\ ${ }^{3}$ Fakultas Agama Islam, Universitas Muhammadiyah Yogyakarta, Yogyakarta \\ diana.nur.fai19@mail.umy.ac.id \\ ${ }^{4}$ Fakultas Agama Islam, Universitas Muhammadiyah Yogyakarta, Yogyakarta \\ anita.aisah@umy.ac.id
}

\begin{abstract}
Abstrak
Pandemi Covid-19 membuat ruang gerak semua orang menjadi terbatas, termasuk pada diri remaja. Remaja yang semestinya bebas untuk bersosialisasi dan berinteraksi, kini terbatasi oleh ruang-ruang online. Remaja disibukkan dengan sekolah online yang membuat lebih sibuk di dunia maya daripada di dunia nyata. Hal ini, tidak hanya menimbulkan kebosanan bagi remaja, melainkan juga berefek pada kesehatan mental remaja, sehingga membutuhkan rekan yang dapat membantu permasalahan yang dialami. Penelitian ini bermaksud untuk mengkaji efektifitas metode workshop dan simulasi sebagai wahana pemberdayaan remaja masjid dalam peningkatan skill konselor sebaya di masa pandemi Covid-19. Pendekatan penelitian mengkombinasikan metode kuantitatif dan kualitatif atau mixed method. Metode pengumpulan data berupa observasi serta wawancara terstruktur, pretest dan posttest. Responden dalam penelitian ini adalah remaja masjid yang berjumlah 22 orang. Data kuantitatif dianalisis dengan statistik deskriptif teknik frekuensi. Adapun data kualitatif dianalisis menggunakan teknik Miles dan Huberman, yaitu; reduksi data, verifikasi data dan penyajian data. Hasil dari penelitian ini adalah berupa peningkatan pengetahuan dan kompetensi yang ditunjukkan remaja masjid setelah mengikuti rangkaian workshop konselor sebaya. Responden yang memiliki pemahaman yang baik pada materi posttest sebesar $87 \%$ dan dalam simulasi responden mampu melakukan praktik konseling sebaya sesuai panduan.
\end{abstract}

Kata kunci: Konseling Sebaya, Workshop, Simulasi

\begin{abstract}
The Covid 19 pandemic limited everyone's space, including adolescents. Online spaces now limit youths who should be free to socialize and interact. Adolescents are preoccupied with online schools, which make them busier in cyberspace than in the real world. This case causes boredom for adolescents and affects their mental health, thus requiring partners to help their problems. This study intends to examine the effectiveness of workshop and simulation methods to empower mosque youth in increasing peer counselor skills during the Covid-19 pandemic. The research approach combines quantitative and qualitative methods (mixed method). The data collection methods were observation, a structured interview, pretest and posttest. Respondents in this study were
\end{abstract}


22 mosque youths. The quantitative data were analyzed by using descriptive statistics with frequency technique. The qualitative data were analyzed using the Miles and Huberman technique consisting of data reduction, data verification, and data presentation. This study's result is increased knowledge and competence shown by mosque youth after participating in peer counselor workshops and simulations. Respondents who had a good understanding of the posttest material were $87 \%$, and in the simulation, respondents were able to practice peer counseling according to the guidelines.

Keywords: Peer Counseling, Workshop, Simulation.

\section{PENDAHULUAN}

Masa remaja sering kali tergambarkan dengan periode anak-anak yang sudah dianggap akil baligh. Pada masa ini, individu sering kali terlibat konflik dan memiliki banyak permasalahan, baik permasalahan dengan diri sendiri atau dengan lingkungan di luar dirinya. Banyak kaum remaja yang belum siap mengimbangi perubahan yang dialaminya, seperti perubahan fisik, tingkat emosi, moral, interaksi sosial dan cara bertindak dan berpikir (Masnuna, Kusuma Wardani, \& Kadiasti, 2020). Kondisi kaum remaja ditandai dengan perubahan sikap sosial, penurunan minat dalam kegiatan kelompok, dan kecenderungan melakukan kegiatan secara individu (Lating, 2016). Remaja di masa ini juga cenderung berani mencoba-coba hal baru untuk memenuhi rasa ingin tahunya. Jika tidak ada teman yang mendampinginya, kaum remaja bisa terjebak dalam kebimbangan bahkan dapat memicu kenakalan remaja. Bagi sebagian remaja, pengalaman ditolak atau diabaikan dapat membuatnya merasa kesepian sehingga dibutuhkan kemampuan baru dalam menyesuaikan diri yang dapat dijadikan dasar dalam interaksi sosial yang lebih besar (Diananda, 2019).

Lebih lanjut, kegiatan remaja menjadi serba terbatas sehingga menimbulkan dampak terhadap perubahan psikologis mereka. Belakangan ini, pada masa terjadinya penyebaran virus corona, banyak remaja hanya menghabiskan waktu untuk tidur kemudian bangun untuk belajar online atau bermain gadget. Hal tersebut menimbulkan kekhawatiran terhadap perubahan kondisi remaja terutama kondisi psikisnya. Dalam kondisi seperti ini banyak sekali remaja yang membutuhkan dukungan psikologis untuk tetap melangsungkan aktifitasnya tanpa ada rasa tertekan dan juga untuk menjaga kesehatan psikisnya. Namun, kebanyakan remaja enggan bercerita kepada orang dewasa untuk memberinya dukungan dan solusi. Ketika menghadapi persoalan-persoalan besar para remaja cenderung akan mengutarakan permasalahannya kapada teman sebaya dibandingkan orang tua atau dan orang yang lebih dewasa (Ridha, 2019).

Remaja sendiri dipahami sebagai individu yang mulai memahami benar dan salah, memahami lawan jenis, memahami peran dalam dunia sosial, dan mampu mengembangkan segala potensi yang dimiliki dalam dirinya (Jannah, 2017). Saat individu memasuki masa remaja, sejak itulah mulai terjadi banyak perubahan pada dirinya (Wardhani, 2012). Perubahan yang paling dirasakan oleh remaja adalah perubahan fisik, psikologis dan pola hubungan sosial. Dibandingkan dengan anak-anak, remaja lebih cenderung dipengaruhi oleh teman sebayanya (Putro, 2018). Hal ini menandakan bahwa pengaruh orangtua semakin lemah terhadap remaja. Remaja lebih banyak dipengaruhi oleh teman-temannya, selain itu remaja akan mulai memiliki pandangan mereka sendiri terhadap sesuatu bersamaan dengan perkembangan pengalaman dan pemikirannya (Wardhani, 2012).

Melihat kondisi remaja seperti yang tergambar di atas, keberadaan konselor sebaya sangat penting keberadaanya baik di masa-masa normal, maupun di masa pandemi Covid- 
19 saat ini. Konselor sebaya atau sering juga disebut peer counselor yaitu orang yang memiliki peran penting yang telah diembankan kepadanya dalam memberikan pelayanan konseling kepada teman sebayanya, untuk membantu mengatasi masalah yang dihadapi teman sebayanya tersebut (Hasbahuddin \& Ilham, 2018). Konselor sebaya dalam pelaksanaannya memanfaatkan persamaan rasa senasib yaitu usia sebaya atau setara sehingga bisa tercipta rasa keterbukaan dan rasa saling percaya untuk menjadi mitra dalam menyelesaikan persoalan-persoalan sehari-hari. Tugas seorang konselor sebaya adalah mendampingi temannya sehingga hubungan ini dapat memberikan rasa nyaman. Teman sebaya dapat menjadi pelaku strategis dan vital untuk membimbing dan mengarahkan kehidupan antar sebaya (Sarmin, 2017). Teman sebaya juga berperan untuk membantu memecahkan masalah rekannya (Astiti, 2019), serta menghindari pengaruh negatif yang ditimbulkan oleh pertemanan dengan teman sebaya. Teman sebaya dapat menjadi peluang bagi upaya fasilitasi kepada remaja lain yang akan memberikan manfaat bukan hanya kepada diri mereka sendiri, tapi juga kepada orang lain (Lating, 2016). Dalam kegiatan fasilitasi teman sebaya, konselor memegang peranan penting dan dapat membantu teman lain sebagai klien dalam memecahkan masalah (Yulismi, 2018).

Penelitian ini memiliki kemiripan dengan beberapa penelitian terdahulu yang berkaitan dengan pemberdayaan remaja masjid. Penelitian Muthmainah memiliki tujuan untuk melakukan analisis terhadap stakeholder remaja dalam mengimplementasikan program Pelayanan Kesehatan Peduli Remaja (PKPR) mengikutsertakan remaja masjid sebagai salah satu subjek penelitiannya dan menggunakan pendekatan penelitian kualitatif serta wawancara dan Focus Group Discussion (FGD) sebagai teknik pengumpulan datanya (Muthmainah, 2013). Siswantara, Soedirham dan Muthmainah dalam penelitiannya yang bertujuan untuk mengidentifikasi persepsi remaja masjid terhadap program kesehatan dan pola intervensi, menggunakan pendekatan penelitian kualitatif, dan teknik pengumpulan datanya adalah interview dan FGD (Siswantara, Soedirham, \& Muthmainnah, 2019). Penelitian Jais, Arifin dan Effendy bertujuan untuk meningkatkan keterampilan hidup melalui metode konseling sebaya dengan remaja masjid sebagai salah satu subjek penelitiannya menggunakan pendekatan kualititatif dengan wawancara sebagai teknik pengumpulan datanya (Jais, Arifin, \& Effendy, 2018). Maryatun dan Indarwati dalam penelitiannya bertujuan untuk mengetahui pengaruh metode Counter of Clinic-Based and Community Empowerment terhadap pengetahuan remaja pada kesehatan reproduksi, penelitian ini menggunakan model intervensi (Maryatun \& Indarwati, 2018). Penelitian lainnya dilakukan oleh Noor dan Andriani yang bertujuan untuk mengetahui peran remaja dalam pelaksanaan program kampung keluarga berencana, penelitian ini menggunakan pendekatan kualitatif dengan observasi dan wawancara sebagai teknik pengumpulan datanya (Noor \& Andriani, 2020).

Berdasarkan pemaparan penelitian-penelitian terdahulu diatas, meskipun terdapat kemiripan subjek penelitian yaitu remaja masjid, namun terdapat beberapa perbedaan mendasar antara penelitian terdahulu dengan penelitian ini, yaitu; (1) pada aspek tujuan penelitian, penelitian ini memiliki tujuan yang berbeda dengan penelitian terdahulu, yaitu; untuk mengetahui efektifitas metode workshop dan simulasi sebagai langkah dalam pemberdayaan remaja masjid dalam peningkatan skill konselor sebaya di masa pandemi covid-19, (2) pada aspek pendekatan penelitian, penilitian ini menggunakan mixed method (kombinasi pendekatan kuantitaif dan kualitatif), (3) pada aspek metode penelitian, penelitian ini menggunakan metode penelitian tindakan, dengan program berupa rangkaian workshop dan simulasi, (4) pada aspek teknik pengumpulan data, penelitian ini menggunakan wawancara terstruktur, observasi, dan dokumentasi, serta pretest-posttest, (5) pada aspek waktu pelaksanaan penelitian, penelitian ini dilaksanakan pada masa pandemi covid 19. Dengan demikian kebaharuan dari studi ini yaitu 
pemberdayaan remaja menggunakan metode workshop dan simulasi konseling sebaya secara praktis dan dilakukan di masa pandemi covid-19.

Penelitian ini secara khusus mengkaji pemberdayaan remaja masjid sebagai bagian dari pembentukan peningkatan skill konselor sebaya di masa pandemi covid-19. Remaja masjid di sini yaitu perhimpunan dan perkumpulan pemuda atau remaja yang biasanya memusatkan aktifitasnya di mushalla atau masjid. Remaja masjid menjadikan tempat ibadah seperti mushalla atau masjid sebagai tempat kegiatan pembinaan akidah, akhlak, ukhuwah Islamiah, kajian keilmuan, dan pengembangan keterampilan (Nuwairah, 2015). Remaja masjid tersebut aktif dalam kegiatan ke-Islaman dan kemasyarakatan di kampung mereka tinggal. Perkumpulan tersebut merupakan perkumpulan remaja yang berorientasi kepada kegiatan-kegiatan kemasyarakatan terutama kegiatan ke-Islaman. Dengan melihat peran dan fungsinya, remaja masjid dapat memiliki peran dan fungsi yang sangat penting bagi pembinaan remaja dan masyarakat (Nuwairah, 2015), khususnya dalam berkontribusi untuk pemberdayaan pemuda lain atau masyarakat lewat kegiatan konselor sebaya.

\section{METODE PENELITIAN}

\section{Rancangan Penelitian}

Penelitian ini menggunakan pendekatan mixed method, yaitu kombinasi antara pendekatan kuantitatif dan kualitatif. Pendekatan mixed method melibatkan pengumpulan data kuantitatif dan kualitatif sebagai tanggapan atas hipotesis penelitian (Creswell \& Creswell, 2018). Penggunaan dua pendekatan secara terintegrasi dapat memudahkan peneliti untuk mendapatkan data yang kompleks dan mendalam mengenai prevalensi, konteks dan pengalaman individu (Leavy, 2017). Metode ini mencakup metode yang akurat dari data kuantitatif dan kualitatif dengan menggunakan teknik pengumpulan data, analisis data dan interpretasi data (Creswell \& Creswell, 2018). Penggunaan metode ini berguna untuk mengevaluasi proses dan hasil program sebuah intervensi (Creswell \& Creswell, 2018).

Desain penelitian yang digunakan dalam penelitian ini adalah penelitian tindakan. Penelitian tindakan adalah suatu pencarian sitematik yang dilaksanakan oleh pelaksana program kegiatan dalam mengumpulkan data tentang pelaksanaan suatu program atau kegiatan, keberhasilan dan hambatan yang ditemui, dan selanjutnya menyusun rencana untuk memperbaiki program yang telah dilaksanakan (Sukmadinata, 2010). Lewin menyebutkan bahwa penelitian tindakan meliputi perencanaan, pelaksanaan program, dan pengamatan (Sukmadinata, 2010). Proses dalam penelitian tindakan digambarkan dalam siklus yang berbentuk spiral, yang terdiri dari; perencanaan (planning), pelaksanaan tindakan (act), mengobservasi proses pelaksanaan tindakan (observe), dan melakukan refleksi (reflect) (Kemmis, McTaggart, \& Nixon, 2014). Siklus ini akan berulang layaknya spiral, seiring tindakan yang direncanakan kembali oleh peneliti. Kriteria sukses dalam penelitian tindakan tidak hanya pada responden yang aktif mengikuti langkah demi langkah program yang dilaksanakan, tetapi terletak pada perkembangan pemahaman dan praktik responden (Kemmis et al., 2014).

Penelitian ini terdiri dari tiga siklus. Pada siklus pertama, peneliti melakukan perencanaan, tindakan berupa workshop dengan pemberian materi secara klasikal, simulasi, evaluasi secara offline, serta pretest dan posttest. Observasi dilakukan selama tindakan diberikan, dan terakhir dilakukan refleksi. Pada siklus kedua, peneliti kembali melakukan perencanaan, melakukan tindakan berupa implementasi konseling sebaya yang dilakukan oleh subjek penelitian dan melakukan evaluasi secara online. Observasi kembali dilakukan selama tindakan berlangsung, dan diakhiri dengan refleksi. Perencanaan kembali dilakukan pada siklus ketiga, dilanjutkan dengan tindakan berupa 
simulasi dan evaluasi secara offline disertai dengan observasi, dan diakhiri dengan refleksi. Alur tindakan pada setiap siklus dapat dilihat pada gambar 1.

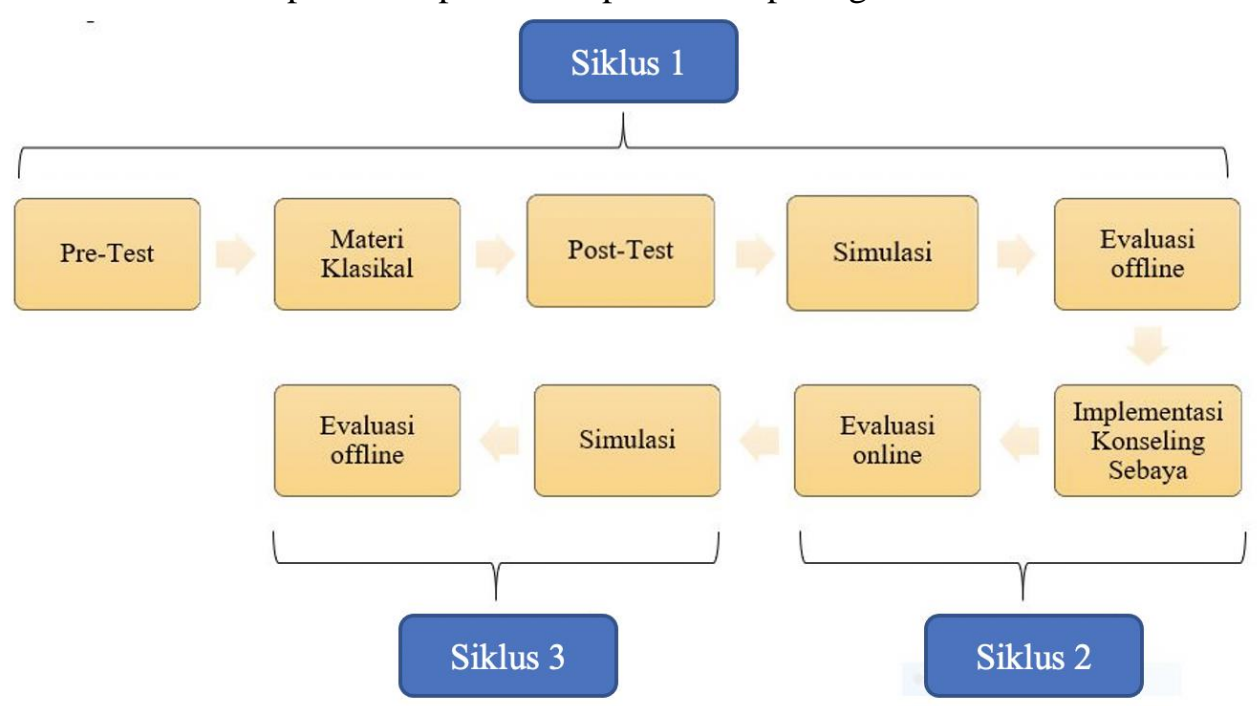

Gambar 1. Alur tindakan pada setiap siklus

Dua tindakan utama yang dilakukan dalam penelitian ini adalah workshop dan simulasi. Workshop merupakan praktik yang memiliki dimensi pengembangan skill peserta dimana peserta aktif dalam mengimplementasikan ilmu yang telah didapat (Westerlund, 2007). Adapun simulasi merupakan metode belajar yang memberikan kesempatan belajar dengan mempraktikan sebuah keterampilan, dengan cara memindahkan situasi yang nyata ke dalam ruang belajar (Mulati, Kuswati, \& Rejeki, 2014).

\section{Sumber Data}

Populasi merupakan wilayah umum yang terdiri atas subjek, objek dan karakteristik tertentu yang ditetapkan peneliti (Sugiono, 2010). Teknik dalam pengambilan sampel adalah nonprobability sampling design, dengan metode purposive sampling. Metode purposive sampling merupakan metode pengambilan data pada sumber data sesuai dengan pertimbangan yang ditentukan oleh peneliti (Sugiono, 2010). Subjek dalam penelitian ini adalah remaja masjid yang berjumlah 22 orang. Kriteria subjek penelitian adalah; anggota yang aktif pada Ikatan Remaja Masjid (IRMAS) dusun Mrisi dengan rentang pendidikan Sekolah Menengah Pertama (SMP) sampai dengan Perguruan Tinggi.

\section{Teknik Pengumpulan Data}

Data dikumpulkan dari hasil observasi, wawancara terstruktur dan dokumentasi serta pretest-posttest. Wawancara terstruktur dilakukan untuk mengevaluasi implementasi konseling sebaya yang dilakukan oleh remaja. Sebelum melakukan wawancara terstruktur, peneliti telah mempersiapkan pertanyaan-pertanyaan dan alternatif jawaban. Wawancara dilakukan dengan menggunakan platform google form. Selain itu, observasi juga dilakukan dalam penelitian ini untuk mengevaluasi proses konseling sebaya yang dilakukan oleh subjek penelitian. Pretest dan posttest berisi materi konseling sebaya yang terdiri dari 3 soal, yaitu; definisi konselor sebaya, manfaat konseling sebaya dan langkah dalam melakukan praktik konseling sebaya. 


\section{Teknik Analisis Data}

Data yang telah terkumpul terdiri dari dua jenis data yaitu data kualitatif berupa hasil observasi dan wawancara dan data kuantitatif berupa angka. Data kuantitatif dianalisis dengan menggunakan teknik statistik deskriptif berupa frekuensi dan presentase. Sementara data kualitatif dianalisis dengan menggunakan teknik Miles dan Huberman. Teknik ini terdiri dari tiga tahap yaitu; reduksi data, penyajian data dan penarikan kesimpulan atau verifikasi (Miles, Huberman, \& Saldana, 2014).

\section{HASIL DAN PEMBAHASAN}

\section{Hasil Penelitian}

\section{Hasil Pelaksanaan Siklus 1.}

Workshop berupa pemberian materi secara klasikal dilaksanakan pada siklus 1 . Sejumlah 22 subjek penelitian mengikuti workshop dengan antusias. Untuk mengukur pemahaman peserta, maka dilakukan pretest sebelum pelaksanaan workshop dan posttest diakhir workshop. Sebelum pelaksanaan pretest, dilakukan brainstorming untuk memetakan permasalahan yang seringkali dialami remaja. Dari hasil brainstorming, diperoleh 11 permasalahan yang seringkali dialami remaja, yaitu; (1) bullying, berupa tekanan teman sebaya, pengucilan dan diancam, (2) penampilan tidak syari, (3) masa pencarian identitas dan jati diri, sehingga cepat terpengaruh dan mengikuti arus, (4) belum mampu melakukan regulasi emosi, sehingga mudah tersinggung, berkelahi dan tidak berfikir logis, (5) masalah percintaan, (7) ingin diperhatikan, (8) pergaulan bebas, (9) persahabatan, (10) keuangan, (11) manajemen waktu, (12) pergaulan negatif, seperti membolos dan minum minumam keras. Dari sebelas masalah tersebut, regulasi emosi merupakan masalah yang banyak dialami remaja, seperti terlihat dalam gambar 2.

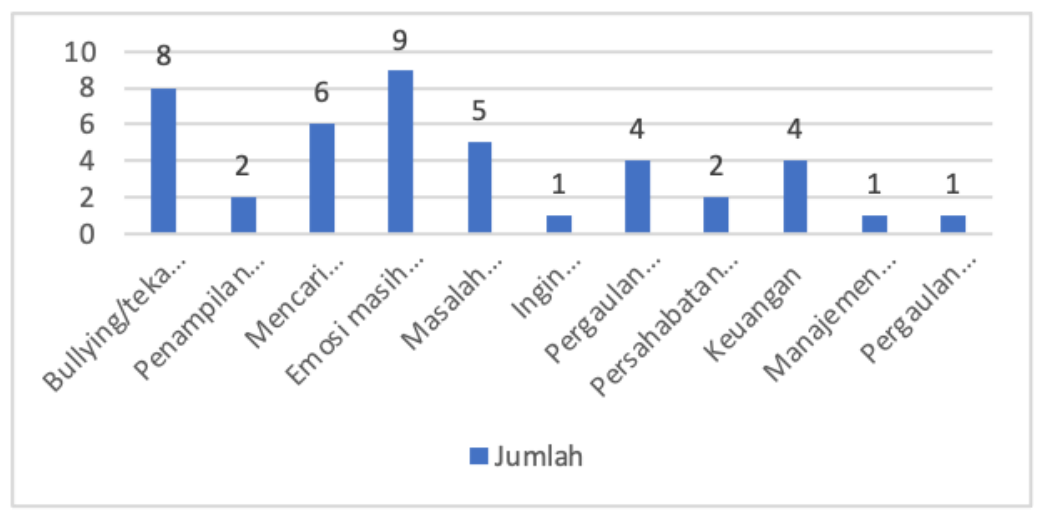

Gambar 2. Pemetaan permasalahan remaja

Pretest dan posttest diberikan kepada subjek penelitian untuk mengukur pemahaman mengenai materi yang diberikan. Pada materi definisi konselor sebaya, dari 22 peserta, 13 peserta atau sebesar 59\% tidak mengetahui definisi konselor sebaya bahkan belum pernah mendengar istilah ini sebelumnya. Sementara sebesar $41 \%$ atau 9 peserta pelatihan menuliskan definisi konselor sebaya dengan beragam definisi, yaitu; sebanyak satu orang menyebutkan bahwa usia konselor sebaya tidak jauh dari klien. Tiga orang menyebutkan bahwa konselor sebaya adalah teman sebaya yang dapat mendengar curhat dan menjaga rahasia. Dua responden menjelaskan bahwa konselor sebaya adalah seseorang yang dapat memberikan solusi dan memutuskan keputusan yang benar atau memecahkan masalah klien. Delapan responden berpendapat bahwa konselor sebaya adalah seseorang yang membimbing dalam pencarian solusi sebuah masalah. Sementara, 
sebanyak 8 remaja lainnya menyebutkan bahwa konselor sebaya merupakan seseorang yang mempunyai keahlian dan bakat dan terlatih dalam melakukan konseling pada teman sebaya. Adapun pada hasil posttest semua responden mengalami peningkatan pemahaman mengenai materi ini, sehingga dapat mendefinisikan konselor sebaya.

Pada pembahasan manfaat konseling sebaya, sebanyak 15 peserta pelatihan atau sebesar $68 \%$ mengetahui manfaat konseling sebaya, sementara $32 \%$ peserta atau sebesar 7 orang peserta pelatihan menyatakan tidak mengetahui manfaat konseling sebaya. Berikut ini merupakan macam-macam manfaat konseling sebaya yang dituliskan peserta; (1) bermanfaat sebagai teman curhat, (2) upaya mengatasi permasalahan remaja, (3) menambah wawasan, ilmu, pengalaman, (4) dapat secara bebas/leluasa dalam menyampaikan unek-unek dan pikiran, karena rekan sebaya biasanya memiliki pemikiran yang sama, (5) untuk membantu menyelesaikan suatu permasalahan yang bersangkutan dengan berbagai masalah remaja, (6) bisa saling terbuka karena merasa sepemikiran, (7) memotivasi, (8) silaturahmi bagi remaja, (9) memberikan perasaan lega kepada yang diberikan konseling karena dapat meringankan beban yang dikirikan remaja, (10) dapat membantu remaja dalam menghadapi permasalahan di usianya, karena remaja terkadang sungkan untuk berbicara dengan orang yang lebih tua dan konseling sebaya dapat menjadi solusi bagi permasalahan remaja, (11) agar remaja semakin dewasa, (12) membenahi mental dan tingkah laku remaja, serta (13) pembinaan pada remaja.

Pada posttest terlihat bahwa pemahaman responden mengenai manfaat konseling sebaya semakin spesifik. Namun demikian masih terdapat 3 responden yang belum paham, dan menjawab dengan jawaban tidak tahu dan menjelaskan bahwa manfaat konseling sebaya adalah untuk menjaga rahasia. Adapun 4 responden kurang memahami manfaat konseling sebaya, karena menjawab bahwa konseling sebaya bertugas memecahkan masalah dan memberi solusi kepada klien. Sedangkan sebanyak 15 responden atau $68 \%$ paham manfaat konseling sebaya, yaitu membantu remaja menyelesaikan masalah dan mampu membuat keputusan serta dengan konseling sebaya remaja akan merasa lebih nyaman dan terbuka saat melakukan konseling, sehingga merasa tenang dan lega.

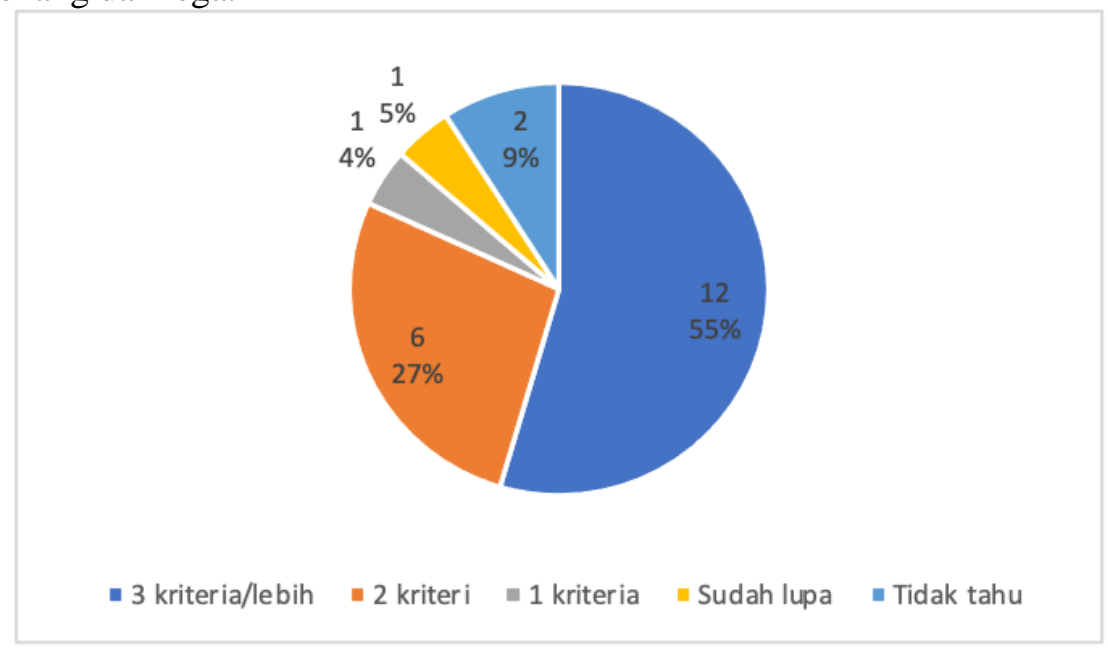

Gambar 3. Cara menjadi konselor remaja

Pretest selanjutnya membahas cara menjadi konselor sebaya yang baik. Sebanyak 14 peserta pelatihan atau sebesar $64 \%$ mengetahui cara untuk menjadi konselor yang baik, sementara 8 peserta pelatihan tidak mengetahui cara menjadi konselor yang baik. Pada sesi posttest sebanyak 12 peserta pelatihan atau 55\% mampu menyebutkan 3 atau lebih kriteria konselor remaja yang baik. Enam peserta atau $27 \%$ mampu menyebutkan 2 
kriteria, 1 peserta pelatihan hanya mampu menyebutkan 1 kriteria. Sementara itu 1 peserta lain mengaku sudah lupa dengan kriteria konselor remaja yang baik, dan 2 orang peserta atau sebesar 9\% menyatakan tidak mengetahui kriteria konselor remaja yang baik. Dengan demikian terdapat peningkatan pemahaman responden mengenai cara menjadi konselor remaja yang baik. Bagan hasil posttest dapat dilihat pada gambar 3 .

Tindakan kedua yang dilakukan pada siklus satu adalah simulasi. Simulasi ini digunakan untuk mengukur kemampuan subjek penelitian dalam mempraktikkan konseling sebaya. Dari hasil simulasi didapatkan 50\% subjek masih belum leluasa dalam menjadi konselor sebaya. Beberapa alasan yang dikemukakan subjek penelitian adalah; merasa bingung dan canggung karena baru pertama kali melakukan praktik konseling sebaya, serta kurang percaya diri karena masih belum hafal mengenai Langkah-langkah dalam konseling sebaya.

\section{Hasil Pelaksanaan siklus 2.}

Pada siklus 2, responden diberikan waktu selama dua bulan untuk dapat mengimplementasikan ilmu konseling sebaya yang sudah didapatkan selama mengikuti workshop. Berdasarkan hasil pendampingan, pada sesi implementasi ini, subjek penelitian lebih leluasa dalam melakukan praktik konseling sebaya. Beberapa hal yang membuat subjek peneltian merasa nyaman, adalah; praktik konseling dilakukan dalam situasi santai, komunikasi selama praktik menggunakan bahasa sehari-hari (terutama Bahasa Jawa), dan konselor merasa nyaman karena tidak dilihat oleh peserta lain. Selanjutnya dilakukan evaluasi secara online melalui platform google form. Hasil evaluasi memuat beberapa hal yaitu; rentang usia responden yang mengisi responden, pendidikan, apakah masih mengingat cara melakukan konseling sebaya, apakah pernah menjadi konselor sebaya, permasalahan yang dialami klien, dan kendala yang dialami selama melakukan konseling sebaya.

Rentang usia responden yang mengisi form evaluasi online adalah 14 sampai 21 tahun, dengan responden terbanyak pada usia 10 dan 20 tahun dengan persentasi masingmasing 25\%. Dari 16 responden yang mengisi form evaluasi, 37,5\% atau 6 responden berpendidikan SMA (Sekolah Menengah Atas), 25\% atau 4 responden pada jenjang kuliah dan 25\% SMP (Sekolah Menengah Pertama), sisanya adalah sudah lulus dan berpendidikan SMK (Sekolah Menengah Kejuruan).

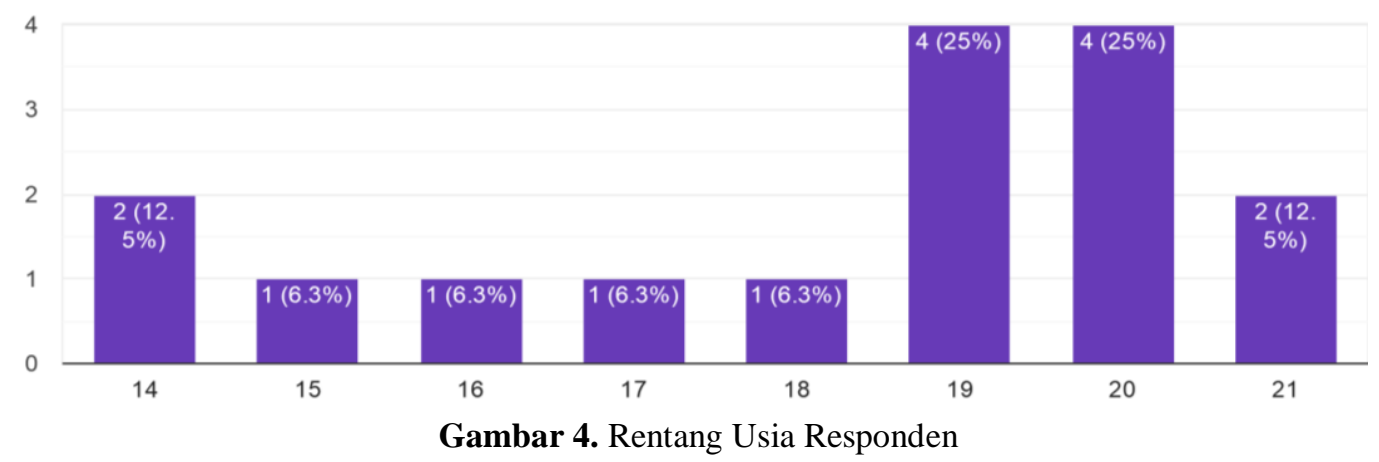

Pelaksanaan evaluasi adalah dua bulan setelah pelatihan, sehingga responden diminta untuk menjawab pernyataan apakah masih mengingat langkah-langkah melakukan konseling sebaya. Sebanyak $81,3 \%$ responden menjawab sangat setuju dan $18,8 \%$ responden menjawab setuju. Sehingga semua responden masih mengingat cara melakukan konseling sebaya. Dalam form evaluasi juga ditanyakan apakah pernah mempraktikan konseling sebaya. Hasilnya adalah hampir semua responden sudah pernah melakukan konseling sebaya, yaitu sebanyak 93,8\%. Untuk kuantitas mempraktikkan 
konseling sebaya, sebanyak $62,5 \%$ atau 10 responden sudah melakukan konseling sebaya lebih dari 3 kali, sementara sisanya adalah melakukan konseling sebaya sebanyak 2 kali yaitu sebesar $18,8 \%$, dan sebesar $12,5 \%$ melakukan konseling sebaya sebanyak 1 kali, sementara sisanya $6,2 \%$ atau 1 orang belum pernah melakukan konseling sebaya.

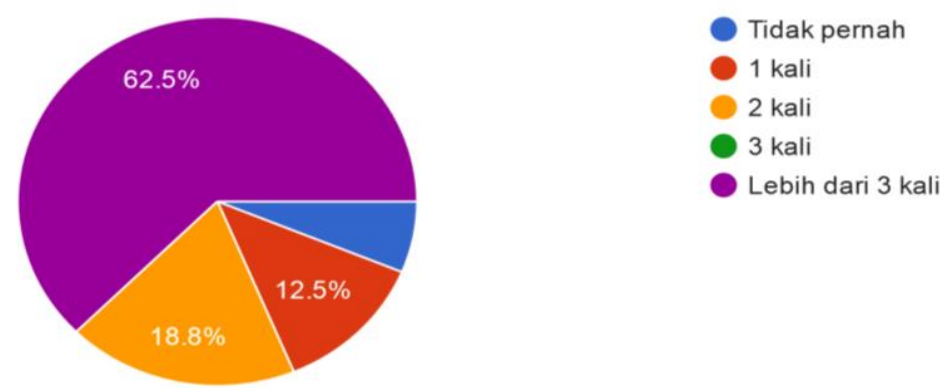

Gambar 5. Kuantitas praktik konseling sebaya

Berkenaan dengan permasalahan klien yang ditangani oleh responden sebagai konselor sebaya, selama melaksanakan konseling sebaya dintaranya; tidak percaya diri, patah hati, perkuliahan, masalah keluarga dan bullying. Adapun kendala yang seringkali dialami ketika pelaksanaan konseling sebaya adalah; kesulitan memberikan solusi yang tepat, klien kurang terbuka, kurang pengalaman dan pengetahuan, dan kurang fokus pada permasalahan klien.

\section{Hasil Pelaksanaan siklus 3.}

Tabel 1. Evaluasi Tindakan Siklus 3

\begin{tabular}{|c|c|c|c|c|c|c|c|}
\hline No. & Kriteria & Peserta 1 & Peserta 1 & Peserta 1 & Peserta 1 & Peserta 1 & Peserta 1 \\
\hline 1 & $\begin{array}{l}\text { Konselor sebaya } \\
\text { (KS) } \\
\text { mendengarkan } \\
\text { secara aktif } \\
\text { permasalahan yang } \\
\text { disampaikan klien }\end{array}$ & $\sqrt{ }$ & $\sqrt{ }$ & $\sqrt{ }$ & $\sqrt{ }$ & $\sqrt{ }$ & $\sqrt{ }$ \\
\hline 2 & $\begin{array}{l}\text { KS mengenali dan } \\
\text { menetapkan jenis } \\
\text { masalah yang } \\
\text { dihadapi klien }\end{array}$ & $X$ & $\sqrt{ }$ & $X$ & $\mathrm{X}$ & $X$ & $\sqrt{ }$ \\
\hline 3 & $\begin{array}{l}\text { KS melakukan } \\
\text { penjajakan } \\
\text { alternatif bantuan } \\
\text { untuk mengatasi } \\
\text { masalah klien }\end{array}$ & $\sqrt{ }$ & $\sqrt{ }$ & $\sqrt{ }$ & $\sqrt{ }$ & $\sqrt{ }$ & $\sqrt{ }$ \\
\hline 4 & $\begin{array}{l}\text { KS menanyakan } \\
\text { keadaan/perasaan } \\
\text { klien setelah } \\
\text { menjalani } \\
\text { konseling sebaya }\end{array}$ & $X$ & $X$ & $X$ & $\mathrm{X}$ & $X$ & $X$ \\
\hline 5 & $\begin{array}{l}\text { KS menegosiasikan } \\
\text { kontrak dengan } \\
\text { klien }\end{array}$ & $\sqrt{ }$ & $X$ & $\sqrt{ }$ & $X$ & $X$ & $\sqrt{ }$ \\
\hline
\end{tabular}

Siklus tiga dilakukan untuk mengkonfirmasi pemahaman peserta pelatihan konselor sebaya terhadap materi yang pernah diberikan dan melihat kembali kemampuan peserta dalam melakukan konseling sebaya. Dari evaluasi ini didapatkan hasil yang 
disajikan pada tabel 1. Dari tabel 1 checklist simulasi diketahui bahwa dari 6 praktikan/peserta belum terdapat praktikan yang mampu melakukan tahapan konseling sebaya dengan sempurna. Semua praktikan lupa untuk menanyakan perasaan klien setelah proses konseling selesai dan hanya 3 dari 6 praktikan yang menegosiasikan kontrak dengan klien untuk proses konseling selanjutnya. Adapun dalam hal mengenali dan menetapkan jenis masalah hanya 2 praktikan yang mampu melakukan, sementara 4 lainnya belum mampu mengenali masalah klien secara lebih jauh. Namun demikian, semua praktikan sudah mampu untuk menjadi pendengar yang baik dan mampu melakukan penjajakan alternatif bantuan untuk diberikan kepada klien.

\section{Pembahasan}

Berdasarkan hasil penelitian diatas, metode workshop dan simulasi dinilai efektif untuk meningkatkan pemahaman responden mengenai pelaksanaan konseling sebaya. Senada dengan Risana et al. bahwa metode workshop dapat meningkatkan pemahaman materi pada responden (Risna et al., 2019). Hal ini terbukti bahwa peserta workshop masih mengingat materi mengenai langkah dalam melakukan konseling sebaya, meskipun sudah diberikan dua bulan sebelumnya. Selain itu peserta juga terbukti dapat mempraktikan rangkaian konseling sebaya dengan tepat pada simulasi tahap pelakasanaan siklus 3. Metode workshop terbukti dalam meningkatkan antusiasme peserta sehingga memberikan dampak positif pada proses pelaksanaan seluruh rangkaian program (Gani \& Gani, 2020), dalam hal ini workshop bimbingan konseling sebaya. Sementara itu, sebuah pembelajaran dapat berjalan dengan maksimal jika menggunakan metode simulasi (Wiharto, 2018). Dalam kegiatan pemberdayaan remaja masjid ini, peneliti menggunakan metode simulasi untuk mengetahui perkembangan kemampuan peserta dalam menyelenggarakan konseling sebaya. Dalam simulasi yang dilakukan, dua orang remaja masjid akan berperan sebagai konselor dan klien, kemudian melakukan praktik konseling sebaya. Senada dengan pendapat Wiharto bahwa sebuah pembelajaran dengan metode simulasi memerlukan keaktifan peserta karena mengutamakan kegiatan dalam bermain peran atau latihan tertertu (Wiharto, 2018). Zulkarnaen, Asriati dan Purwaningsih menjelaskan bahwa pembelajaran dengan metode simulasi dapat meningkatkan aktifitas dan hasil dari proses belajar tersebut (Zulkarnaen, Asriati, \& Purwaningsih, 2015). Simulasi konseling sebaya dalam penelitian ini berdampak positif untuk meningkatkan pemahaman dan kemampuan remaja masjid dalam menyelenggarakan praktik konseling sebaya.

Dalam implementasi konseling sebaya, peserta yang mengimplementasikan konseling sebaya lebih dari dua kali, adalah peserta dengan pendidikan SMA (Sekolah Menengah Atas), SMK (Sekolah Menengah Kejuruan) dan Perguruan Tinggi. Sementara peserta yang berpendidikan SMP (Sekolah Menengah Pertama) baru satu kali bahkan ada yang belum pernah mengimplementasikan konseling sebaya. Hal ini disebabkan oleh rasa tidak percaya diri peserta pada keterbatasan pengetahuan mengenai konseling sebaya, karena peserta menganggap pengetahuan ini merupakan hal yang baru. Senada dengan hasil temuan Ismiyati dalam penelitiannya bahwa 50\% remaja yang menjadi pengurus Pusat Informasi dan Konseling Remaja (PIKR) menyatakan kurang percaya diri dalam memberikan konseling kepada teman sebayanya karena salah satu penyebabnya adalah merasa kurang memiliki pengetahuan atau informasi (Ismiyati, Walessa, Sunjaya, \& Susanah, 2019). Sementara itu kendala lain juga dihadapi oleh peserta yaitu; klien kurang terbuka, kurang fokus pada klien, kurang mampu mengenali dan menetapkan jenis masalah yang dihadapi klien, dan lupa menanyakan perasaan klien setelah konseling sebaya. 
Kendala yang dihadapi peserta sebagai konselor sebaya berupa klien yang kurang terbuka. Senada dengan temuan Astiti bahwa klien atau konseli seringkali mengalami kesulitan dalam mengutarakan perasaan dan mempertahankan perspektif pribadi (Astiti, 2019). Sikap klien yang tertutup disini, disebabkan karena proses konseling sebaya baru saja dilaksanakan oleh remaja masjid, sehingga beberapa klien belum menaruh kepercayaan penuh terhadap konselor sebaya yaitu remaja masjid. Dalam menghadapi kendala ini, remaja masjid perlu dilatih keterampilan berinteraksi agar klien merasa setara atau sama dengan konselor sebaya (Hendrik \& Elmansyah, 2018). Selain itu konselor perlu membangun hubungan baik dengan klien dengan cara menampilkan tingkah laku verbal dan nonverbal yang baik (Ismiyati et al., 2019). Penyebab lain yang membuat klien kurang terbuka adalah klien tidak leluasa karena simulasi dilaksanakan di tempat terbuka. Ruang konseling seharusnya nyaman baik bagi konselor maupun klien. Ruangan perlu disiapkan tata letaknya agar nyaman, aman dan kondusif, serta tidak terdapat bendabenda berbahaya (Ismiyati et al., 2019).

Kesulitan lain yang seringkali dialami konselor sebaya adalah kurang fokus pada klien. Beberapa remaja masjid sebagai konselor sebaya merasa kurang fokus terhadap klien karena gangguan handphone yang dibawa oleh konselor atau klien. Handphone seringkali masih aktif saat proses konseling sedang berlangsung sehingga baik klien maupun konselor kurang fokus dengan sesi konseling. Hal ini membuat proses konseling sebaya menjadi tidak maksimal. Ruang konseling harus dalam keadaan tenang tanpa gangguan dari lingkungan sekitarnya (Ismiyati et al., 2019), termasuk gangguan yang ditimbulkan dari handphone konselor maupun klien. Pada sesi simulasi telah diberikan materi bahwa konselor harus menjadi pendengar aktif, namun pada pada sesi implementasi remaja sebagai konselor sebaya seringkali lupa untuk me-non aktifkan handphone-nya.

Kesulitan para konselor sebaya saat implementasi lainnya adalah kurang mampu mengenali dan menetapkan jenis masalah yang dihadapi klien. Kendala ini dapat terjadi karena beberapa hal, yaitu; klien kurang terbuka dan konselor kurang dapat menggali permasalahan klien. Kesulitan dalam menggali permasalahan klien, berdasarkan penelitian Tiara dan Pratiwi, dapat diatasi dengan beberapa cara, antara lain; meminta klien menuliskan hal yang ingin diceritakan kepada konselor dan konselor memulai pembicaraan dengan bahasa keseharian atau non formal (Tiara \& Pratiwi, 2018). Kendala yang terakhir adalah lupa menanyakan perasaan klien setelah konseling sebaya berlangsung. Hampir semua peserta pada simulasi siklus 3 tidak melakukan tahapan ini, dengan alasan lupa. Beberapa peserta menyatakan bahwa karena sudah terlalu banyak melakukan percakapan dengan klien sehingga melupakan tahapan ini. Disini terlihat kepedulian konselor terhadap perasaan klien masih rendah. Klien akan merasa kecewa pada konselor yang kurang peduli terhadap masalah yang sedang dihadapinya (Ismiyati et al., 2019), oleh karena itu konselor sebaya perlu meningkatkan empati atau kepeduliannya terhadap klien.

Berdasarkan beberapa kendala yang masih dialami remaja masjid dalam mengimplementasikan konseling sebaya sehingga proses pendampingan tidak hanya dilaksanakan satu kali saja, melainkan secara berkelanjutan. Senada dengan pendapat Hendrik dan Elmansyah, bahwa untuk meningkatkan kompetensi konselor sebaya seharusnya dilakukan pembinaan dan pendampingan konseling sebaya yang kontinyu (Hendrik \& Elmansyah, 2018). Dengan pendampingan yang berkelanjutan, diharapkan kendala-kendala yang dialami remaja sebagai konselor sebaya dapat teratasi. 


\section{SIMPULAN}

Berdasarkan hasil pembahasan diatas dapat disimpulkan bahwa rangkaian workshop konseling sebaya efektif dalam mengedukasi remaja masjid dalam melakukan praktik konseling dengan teman sebaya sebagai klien. Meskipun demikian, beberapa kendala masih dialami konselor seperti; klien kurang terbuka, kurang fokus pada klien, kurang mampu mengenali dan menetapkan jenis masalah yang dihadapi klien, dan lupa menanyakan perasaan klien setelah konseling sebaya. Namun demikian, para remaja masjid sudah cukup percaya diri untuk melakukan praktik konselor sebaya di lingkungan masing-masing. Proses pendampingan masih perlu dilakukan agar remaja masjid dapat melakukan konseling sebaya dengan baik dan maksimal. Dalam proses pendampingan ini perlu melibatkan konselor atau guru bimbingan konseling yang telah berpengalaman dalam membantu mengatasi masalah remaja. Adapun saran bagi penelitian selanjutnya, adalah agar menggunakan metode lain dalam upaya peningkatan kemampuan konseling sebaya, sehingga dapat memperkaya khazanah keilmuan dalam ruang lingkup metode Bimbingan Konseling.

\section{UCAPAN TERIMAKASIH}

Ucapan terima kasih diberikan kepada Lembaga Penelitian, Publikasi dan Pengabdian Masyarakat (LP3M) Universitas Muhammadiyah Yogyakarta sebagai pemberi dana hibah, juga kepada takmir masjid dan remaja masjid dusun Mrisi, serta semua pihak yang telah membantu kelancaran kegiatan ini.

\section{DAFTAR PUSTAKA}

Astiti, S. P. (2019). Efektivitas Konseling Sebaya (Peer Counseling) dalam Menuntaskan Masalah Siswa. IJIP : Indonesian Journal of Islamic Psychology, 1(2), 243-263. https://doi.org/10.18326/ijip.v1i2.243-263

Creswell, J. W., \& Creswell, D. J. (2018). Research Design Qualitative, Quantitative, and Mixed Methods Approaches (Fifth Edit, Vol. 5). Los Angeles: Sage.

Diananda, A. (2019). Psikologi Remaja Dan Permasalahannya. Journal ISTIGHNA, 1(1), 116-133. https://doi.org/10.33853/istighna.v1i1.20

Gani, H. A., \& Gani, A. W. (2020). Kesadaran remaja dalam mengenali jenis dan dampak narkotika dan psikotropika. Seminar Nasional Pengabdian Kepada Masyarakat, 2019(10), 639-640.

Hasbahuddin, S., \& Ilham, M. (2018). MATAPPA: Jurnal Pengabdian Kepada Masyarakat Pelatihan Konselor Sebaya Sebagai Strategi Pemecahan Masalah Siswa. 1(2012).

Hendrik, H., \& Elmansyah, T. (2018). Meningkatkan Keterampilan Interpersonal Melalui Konseling Teman Sebaya Sekolah Menengah Atas Negeri 1 Segedong. JBKI (Jurnal Bimbingan Konseling Indonesia), 3(1), 22. https://doi.org/10.26737/jbki.v3i1.531

Ismiyati, I., Walessa, R., Sunjaya, D. K., \& Susanah, S. (2019). Model Modul Konseling Sebaya Tentang Kesehatan Reproduksi Remaja. Jurnal Medikes (Media Informasi Kesehatan), 6(2), 273-286. https://doi.org/10.36743/medikes.v6i2.191

Jais, M., Arifin, I. Z., \& Effendy, D. I. (2018). Konseling Teman Sebaya untuk Meningkatkan Lifeskill Remaja. Irsyad: Jurnal Bimbingan ..., 6, 57-75. Retrieved from http://jurnal.fdk.uinsgd.ac.id/index.php/irsyad/article/view/873

Jannah, M. (2017). Remaja Dan Tugas-Tugas Perkembangannya Dalam Islam. Psikoislamedia : Jurnal Psikologi, 1(1), 243-256. https://doi.org/10.22373/psikoislamedia.v1i1.1493

Kemmis, S., McTaggart, R., \& Nixon, R. (2014). The Action Research Planner: Doing 
Critical Participatory Research. In Action Research. Singapore: Springer.

Lating, A. D. (2016). Konflik Sosial Remaja Akhir (Studi Psikologi Perkembangan Masyarakat Negeri Maamala Dan Morella Kecamatan Leihitu Kabupaten Maluku Tengah). Jurnal Fikratuna, 8(1), 23-35.

Leavy, P. (2017). Research Design. In The Guilford Press. New York: The Guilford Press.

Maryatun, \& Indarwati. (2018). Counter of Clinic-Based and Community Empowerment Upaya Preventif Perilaku Beresiko pada Remaja Masjid Jami' Kabupaten Sukoharjo. 2(2), 119-128.

Masnuna, M., Kusuma Wardani, N. I., \& Kadiasti, R. (2020). Desain Aplikasi SALIM sebagai Media Pembelajaran untuk Menanggulangi Tindakan Kenakalan Remaja. ANDHARUPA: Jurnal Desain Komunikasi Visual \& Multimedia, 6(1), 100-114. https://doi.org/10.33633/andharupa.v6i1.3327

Miles, M. B., Huberman, M. A., \& Saldana, J. (2014). Qualitative Data Analysis: A Methods Sourcebook. In BMC Public Health (Third Edit, Vol. 5). California: Sage Publication.

Mulati, T. S., Kuswati, \& Rejeki, A. S. (2014). Perbedaan Pengaruh Metode Pembelajaran Simulasi Dengan Latihan (Drill) Terhadap Penerapan Pengisian Partograf Pada Mahasiswa DIII Kebidanan. Jurnal Cakrawala Pendidikan, 1(1), 113-119. https://doi.org/10.21831/cp.v1i1.1867

Muthmainah. (2013). Analisis Stakeholder Remaja Terhadap Implementasi Program Pelayanan Kesehatan Peduli Remaja (PKPR) di Kota Semarang. Jurnal Promosi Dan Pendidikan Kesehatan Indonesia, 1, 170-183.

Noor, M. L., \& Andriani, A. D. (2020). Peran Remaja Dalam Program Kampung Keluarga Berencana $(\mathrm{Kb})$ Barukupa Kabupaten Cianjur. Jurnal Komunikasi Universitas Garut: Hasil Pemikiran Dan Penelitian, 6(1), 399-412.

Nuwairah, N. (2015). Peran Keluarga dan Organisasi Remaja Masjid Dalam Dakwah Terhadap Remaja. Al-Hiwar, 3(6), 1-12.

Putro, K. Z. (2018). Memahami Ciri dan Tugas Perkembangan Masa Remaja. Aplikasia: Jurnal Aplikasi Ilmu-Ilmu Agama, 17(1), 25. https://doi.org/10.14421/aplikasia.v17i1.1362

Ridha, A. A. (2019). Penerapan Konselor Sebaya dalam Mengoptimalkan Fungsi Layanan Bimbingan Konseling di Sekolah. Jurnal Psikologi, 15(1), 25. https://doi.org/10.24014/jp.v15i1.6549

Risna, K., Giri, P., Wayan, N., Utami, A., Tinggi, S., \& Bali, D. (2019). Melalui Sosialisasi Dan Workshop Kreativitas. Jurnal Lentera Widya, 1(1), 8-14.

Sarmin, S. (2017). Konselor Sebaya: Pemberdayaan Teman Sebaya dalam Sekolah Guna Menanggulangi Pengaruh Negatif Lingkungan. Briliant: Jurnal Riset Dan Konseptual, 2(1), 102. https://doi.org/10.28926/briliant.v2i1.30

Siswantara, P., Soedirham, O., \& Muthmainnah, M. (2019). Remaja Sebagai Penggerak Utama dalam Implementasi Program Kesehatan Remaja. Jurnal Manajemen Kesehatan Indonesia, 7(1), 55-66. https://doi.org/10.14710/jmki.7.1.2019.55-66

Sugiono. (2010). Metode Penelitian Pendidikan (Pendekatan Kuantitatif, Kualitatif, dan $R \& D)$. Bandung: Alfabeta.

Sukmadinata, N. S. (2010). Metode Penelitian Pendidikan. Bandung: Remaja Rosdakarya.

Tiara, S., \& Pratiwi, M. R. (2018). Proses Pendampingan Melalui Komunikasi Teurapetik Sebagai Pemulihan Psikologis Korban Pemerkosaan. Jurnal An-Nida, 10(2), 189205. Retrieved from https://ejournal.unisnu.ac.id/JKIN/article/viewFile/790/1057

Wardhani, D. T. (2012). Perkembangan dan Seksualitas Remaja. Sosio Informa, 17(03), 
184-191. Retrieved from https://ejournal.kemsos.go.id/index.php/Sosioinforma/article/download/84/52

Westerlund, B. (2007). A Workshop Method that Involves Users Talking, Doing and Making. Human Machine Interaction Conference.

Wiharto, M. (2018). Kegiatan Lesson Study Dalam Pembelajaran. Forum Ilmiah, 1, 1-9. Retrieved from https://www.esaunggul.ac.id/wp-content/uploads/2018/02/1.Kegiatan-Lesson-Study-Dalam-Pembelajaran.pdf

Yulismi, M. (2018). Konseling Keluarga pada Keluarga dengan Anak Berkebutuhan Khusus. Edutech, 17(1), 110-125.

https://doi.org/https://doi.org/10.17509/e.v1i1.12368

Zulkarnaen, Asriati, N., \& Purwaningsih, E. (2015). Penerapan Model Pembelajaran Simulation pada Mata Pelajaran Ekonomi Siswa di SMA. Jurnal Pendidikan Dan Pembelajaran Khatulistiwa, 4, 1-12. 